\title{
Madhesis' Consciousness of Geopolitics of the Tarai: A Resource for the Collective Identity Assertion
}

Pandey Nirodh

\begin{abstract}
This article examines the broader political and economic historical contexts within which the central Tarai was incorporated into the Nepali state since the so called national unification in the second half of the eighteenth century and subsequently how the relationship between the successive rulers and the Madhesi people has been remaining confrontational. Based on the data drawn from the historiography of Nepal vis-à-vis the central Tarai and the perceptions and experiences of Madhesi people regarding their identity issues, it is argued that historically evolving geopolitics of the central Tarai and the contingent Madhesis' self-consciousness have provided the cause and context for organizing and mobilizing them for the assertion of distinct collective identity.The strategic geopolitical location and significant cultural distinction and economic strength of the central Tarai provided Madhesi people a leverage in the struggle for the recognition of their distinct identity.
\end{abstract}

Keywords: Geopolitics, space, Madhesi people, collective identity, consciousness

\section{The Problem}

What is the relationship between geopolitics and identity? How does the historically evolving geopolitics of a place and the emerging consciousness of the people living in that place shape or reproduce the process of identity assertion? These are the crucial questions examined in this article for the understanding of the process of the assertion of collective identity by a distinct group of people. Insisting that geopolitics of a place - the interplay of history, geography, culture, economy, language, caste/ethnic composition - provides a stage for identity assertion, negotiation, and contestation, this article examines the broader political and economic historical contexts within which the Tarai, particularly the central Tarai was incorporated into the Nepali state since the so called national unification in the second half of the eighteenth century and consequently how the relationship between the successive rulers and Madhesi people ${ }^{1}$ has beenremainingconfrontational. The major foci of this article are on how have Madhesi people viewed 'Tarai as the geography of colonization' (Rai, 2013) by Pahadi rulers, how have they begun to perceive themselves as subjects to be ruled from successive rulers, and over time, how have they attempted to capsize the history

\footnotetext{
${ }^{1}$ Only the caste Madhesis have been considered as Madhesi people throughout this study.
} 
to redress the socio-cultural, political-economic and even psychological grievances they had been witnessing for long. In other words, this is the study of the intersection of historical trajectories and current specificities in which assertion of Madhesi identity has been made. It is built on the premise that the current assertion of Madhesi identity can only be understood in terms of the historical emergence of geopoliticsof the Tarai as perceived by Madhesi people.

\section{Method}

This article uses both primary and secondary data. The perceptions and lived experiences of Madhesi individuals regarding the relationship of their identity with the evolving geopolitics of the Tarai were acquired through the informal conversations during the field work in Birganj in March 2018. The secondary data were drawn from the historiography of Nepal vis-à-vis the central Tarai. Both sets of data have been used to supplement and complement each other.

\section{Conceptual Framework}

For having a better understanding of the context and process of collective assertion of Madhesi identity, it is necessary to delve into the historical process of production of the central Tarai territory, primarily a Madhesi settlement as "state space” (Scott, 2009). "State space," according to James Scott, is an ideal space for appropriation in order to ensure a reliable supply of labor, revenue, rents, food, tradable goods and other means for the state and its rulers (as cited in Rai, 2013, p. 42). Viewed through Scott's analytical tool "state space," it becomes evident that the Tarai region developed and has still remained as a major source of extraction (see Regmi, 1972 \& 1978) for sustaining Nepali state since the time of unification.Therefore, Madhesi peoples'deep-seated sense of resistance againstthe state power and their regional cultural identity based struggle for territorial claim - especially the demand of autonomous Tarai-Madhes with political and economic right under the federal system can be explored within the ambit of production of Tarai as "state space.”

In a similar vein, "space” as conceptualized by Michael (2013) enables us to view the production of Tarai territory as a power-laden, culturally determined, contentious process involving access to resources, both material and symbolic, that are derived from agrarian environments. The Tarai as a "space” has to be conceptualized as a dynamic entity produced out of a shifting ensemble of meanings, practices and interrelationships involving human communities, institutions (such as the state) and struggles to define and control resources (Michael, 2013, p. 5). Drawing on Bourdieu (1989), it can be said that the Tarai as a social space with multiple dimensions (economic, cultural, social and symbolic capital) is a field of forces, the locus of power struggles. In what follows it will be illustrated that Madhesis' 
assertion of identity can better be understood as the struggle for (re)claiming the "space" so as to establish their share in state's political power and economic resources. Peoples' sense of attachment to their lived places can be a powerful motivation driving the political actions that people undertake to defend and reclaim their places (as cited in Rai, 2013, p. 280).

\subsection{Production of Tarai ${ }^{2}$ as "State Space"}

Nepali Tarai took nearly a hundred years (from 1775 - 1875) to crystallize in its present form (Michael, 2013). It emerged out of a process of territorial consolidation as the Gorkhali state expanded conquering hill kingdoms and laying claim to their possessions in the plains (Michael, 2011). However, the history of the Tarai during the hundred years of its formation and prior to this period too witnessed several upheavals that got manifest in terms of collusion over the jurisdiction of its land and resources between different political powers of the hills and the plains. In the mid-eighteenth century, the eastern Tarai districts of Parsa, Bara, Rautahat, Saptari and Mahottari were under the control of petty hill kingdom of Makwanpur (Regmi, 1972; Michael, 2011 \& 2013). The Sen Kings of Makwanpur conquered the eastern Tarai from kings of plains origin whose locus of power was in what is now Bihar (Gaige, 2009, p. 24).

As Prithvi Narayan Shah conquered Makwanpur in 1762 in the course of what is popularly called unification, he claimed the possessions in the Eastern Tarai. The kingdom of Makwanpur was annexed primarily because Indo - Tibetan trade route via Kathmandu was under its control and its annexation enabled Gorkha rulers to control Sindhuli-Gadhi which mediated the contact of Kathmandu to the India through the eastern Tarai districts of Parsa, Bara and Rautahat (Regmi, 1972; Michael, 2013). Contrary to some historians (such as D. R. Regmi, 2007[1961]) who praise and glorify the nationalist spirit of Prithivi Narayan Shah as the catalytic factor for the political unification of Nepal, economic historian Mahesh Chandra Regmi (1972) argues that the motive behind territorial expansion of the Kingdom of Gorkha was economic one. An analysis of the pattern of Prithvi Narayan Shah's military campaigns indicates that the underlying objective was to gain control of territory in the Tarai as well as the trade routes between India and Tibet (Regmi, 1972, p. 9). In a letter written to one of his generals on the eastern front in 1774, Prithvi Narayan Shah described the Tarai as "superior and revenue-yielding territory" and the hill region as "inferior territory" and added, "We should not relinquish territory in the Tarai...even if there is war" (as cited in Regmi, 1972, p. 9).

\footnotetext{
${ }^{2}$ Madhesi intellectuals, leaders and activists prefer to use the term Madhes instead of the Tarai. For them, Madhes is not merely a geographical entity but also a cultural region. For the purpose of present study, without delving much into the semantic debates on Tarai and Madhes, both the terms have been used interchangeably.
} 
The Tarai had multiple ramifications to the expanding Gorkha state.The relative abundance of virgin land in the Tarai offered an opportunity to meet post-unification political as well as economic needs (Shrestha, 2001 [1990]). Tarai provided the financial support for army maintenance and expansion; it provided the saltpeter required for manufacturing of ammunitions; and many army veterans had stakes in Tarai in the form of land grants (Sah, 2017). Nepali rulers realized that they could not survive and continue the expansion of the country without the Tarai. For these reasons, Gorkha rulers wanted to restore the Tarai when they lost control over it subsequent to the defeat in Anglo-Gorkha war and in this connection, a representative of Gorkha rulers wrote to British representative: "Never will we consent to give up to you the Tarai; take the Tarai, and you will leave us without the means of subsistence, for the hills, without it, are worth nothing. The Tarai is of no use to you, because your people cannot live in it, or keep it, and in wresting it from your hands we will devastate your provinces down to the Ganges” (as cited in Sah, 2017, p. 121). This implies that Tarai was of utmost strategic importance for Gorkha rulers to fulfill the dream of greater Nepal.

Gorkhali claims to the Tarai lands were usually made on grounds of a host of tribute, taxation, and tenurial claims they had inherited by virtue of territorial conquest (Michael, 2011). However, it seems contradictory to assert, as Ojha (1983) argues, "Before unification asssslmost all of the current Tarai region was under the jurisdiction of various hill states and principalities”(p. 21). Prior to and also following Gorkha occupation in the Eastern Tarai, the control over the districts of Parsa, Bara and Rautahat also called as Thathar/Tauter seemed fluctuated (see Michael, 1999, 2011, 2013). Despite the claim of possession by Gorkha rulers, these districts remained under the occupation of the East India Company until January 1771 (Regmi, 1972). The claims over some Tarai regions by Gorkha rulers were disputable as hill Rajas had negotiated tenure rights with the Rajas of the plains (Stiller, 1976). Nepal had paid tribute to the East India Company for tenure rights in the Makwanpur Tarai until the East India Company had signed away their claim to this tribute in the treaty of October 1801 (Stiller, 1976). Jha (2017 [1993], p. 5) mentions that the Tarai region, whether in possession of the Sen or Shah kings, was under the suzerainty of the 'Saltanat' of Mughul emperors and the East India Company (Calcutta) of India and, therefore, they had to pay rent for using the resources of this region.

Between 1765 and 1814, Gorkha and the English East India Company witnessed a phase of territorial expansion which culminated in the outbreak of serious territorial disputes along the Champaran - Tarriani frontier (Michael, 2013, p. 31). The dispute about the TautarPraganna so long enjoyed by the ruler of Makwanpur as a landlord was from the very beginning keeping the conflict between the British and Gorkhalis alive (D. R. Regmi, 
2007 [1961], p. 248). Such dispute resulted from the claim over certain frontiers in the border areas by both powers was the immediate cause of the war between Gorkha and East India Company in 1814 - 1816 (Rose, 1971; Michael, 2013). At the time of Anglo-Gorkha War, the Champaran - Tarriani section was formed by the northern reaches of sarkarChamparan and Gorkha's Eastern Tarai districts (Michael, 2013, p. 18). As Nepal was defeated in the war, it was compelled to relinquish its considerable territories of the Tarai to the East India Company, with the exception of Morang; but such territories were shortly returned to Nepal (Regmi, 1972). East India Company occupied Tarai in November 1814 and a Memorandum was signed on December 1816 to give Tarai to the Gorkha (Sah, 2017).

Following political unification, especially in the eastern Tarai, land grants and assignments to the member of nobility, military officials and members of other selected groups under the Birta and Jagir systems formed the bedrock of the political and administrative set-up for maintaining the grip on state authority (Regmi, 1972; Stiller, 1976). At the turn of the nineteenth century the Gorkha rulers referred to their territorial domain in terms of a Persian loanword meaning possessions (muluk) or, more precisely, "the entire possessions of the king of Gorkha” (gorkha raj bharmuluk)(Burghart, 1984, p. 103).

It is argued, mostly by Madhesi activists, that snatching the land from the real owner, the Madhesis, the Shah and Rana Rulers distributed the Tarai land to certain groups from the hills acknowledging the services rendered to them (Thakur, 1996; Goait, 2007). The land grant and assignment policy followed by the Gorkhali rulers favored particular classes and communities in the society to the exclusion of others (Regmi, 1972). Successive rulers in Kathmandu consistently followed the policy of debarring the inhabitants of the Tarai region from political power as well as from appointments in the civil administration and the army (Regmi, 1984, p. 13).

Ceding eastern Tarai to Gorkha rulers by East India Company without the consent of Madhesi people has been taken by some Madhesi intellectuals as conspiracy against Tarai people. Goait (2007) claims that Tarai people who made the land of Tarai cultivable had been suffering from cruelty, injustice and inhumane behaviors of Shah Rulers and subjected to monetary exploitation in fulfilling ruler's interests. Gorkha rulers suppressed the rights of the people of Madhes who neither had their own police nor army; neither have they had their own judicial authorities nor law makers (Thakur, 1996). So, Madhesi people wanted emancipation from Gorkha rulers' cruelty and for which they supported East India Company in the Anglo - Gorkha war (Thakur, 1996; Goait, 2007; Sah, 2017). During its occupation in the Tarai, East India Company collected tax, made arrangement of security, engaged with different groups of people and surveyed different places (Sah, 2017). In a letter written to Secretary to British government in India on 12 December, 1814, Bradshaw, a leader of 
British force in Tarai mentioned, "The inhabitants in general of the Tarai have manifested satisfaction at being taken under the protection of the British government” (cited in Sah, 2007, p. 115). The $7^{\text {th }}$ point of the Memorandum signed by British official on December 1816 paid the concern of the security of Tarai inhabitants: "Moreover, the Rajah of Nipal agrees to refrain from prosecuting any inhabitants of Tarai, after its revertance to his rule, on account of having favoured the cause of the British Government during the war, and should any of those persons, excepting the cultivators of the soil, be desirous of quitting their estates, and of retiring within the Company's territories, he shall not be liable to hindrance" (as cited in Jha, 2017). Nonetheless, Madhesi dwellers were ill-treated, tortured, and punished on the charges of treason labeling them as 'followers of British and adversary of Nepali' (Pathak and Upreti, 2009).

Obviously, fluctuating control over eastern Tarai might have created dilemma among its inhabitants in their political accommodation and hence fear and insecurity. As the political identity of Nepali Tarai until the mid-nineteenth century was not permanently confined to any particular state (Bhattarai, 2000), Madhesis' national identity had yet incipient. It is argued that ever since the Treaties (of 1816 and 1860) signed between Nepal and British India that defined the boundary of Nepal in the south, the Madhesi people have been facing an identity problem (Jha, 2017; Sah, 2017). Madhesi political activist Raghunath Thakur strongly asserts that Madhes is a country that has its own traditions, distinct ethnicity and is in a state of dependency for centuries; yet, the people of Madhes can live within a good order if their human rights are protected/ ensured (Thakur, 1996).

It has been perceived that in order to subordinateMadhesi people, separate laws for taxation and social control had been made during the Rana regime (Thakur, 1996; Sah, 2017). Madhesis were differently treated by the rulers misrecognizing them as outsiders. Some Madhesi people fled from the Madhes as they could not tolerate the economic suppression they had to encounter. The biased state policies made difficult for Madhesis to have equal access in political power and socio-economic privileges. The post-Rana governments too adopted such unfavorable policies on land ownership,citizenship, language and political representation that isolated and alienated the Madhesi population from the national framework (see Gaige, 2009).

\section{The Birganj Nexus}

Rana Prime Minister Bir Shamsher conferred his name to an existing settlement called Gahawa as Birganj in 1897 (Stiller, 1993; Whelpton, 2005; Lal, 2020). It is believed that Bir Shamser sent two hakims (officers) from Kathmandu to facilitate the expansion of 
settlement by providing land and timbers clearing the forest ${ }^{3}$.Giri (2016) has argued that conception of Birganj had begun at that time in history when relationship between Kathmandu and Tibet went worsening during the reign of Janga Bahadur Rana.During the reign of second Rana prime-minister Ranodwip, instead of Lhasa of Tibet, Kolkata of India stood as an alternative point for trade (Giri, 2016). In such context, the place later named as Birganj became an appropriate siteto be developed as a main trade transit point between Nepal and India especially for being at a close distance from the capital Kathmandu and at a convenient point to deliver the goods from Indian cities and sea ports.

Birganj lured the governing elites of Nepal during Shah and Rana reign.Several Shah and Rana elites arrived at Birganj because of power struggle at Kathmanduand occupied land in and around it $^{4}$. Succeeding Rana Prime-ministers allotted birta land to their bharadar in the Tarai. Indeed, Thakuri and Rana elites had monopolized the control over the land of Madhes (Giri, 2016). However, as revealed through the oral history shared to me by research participants, the indigenous Madhesi community living in and around Birganj never got land from the rulers leaving aside very few exceptions; few Madhesi elites who had close connection to the rulers and rendered the services to them politically and economically got access to the land and resources. Madhesis asserted that their alienation in terms of land and resources and power exercise at local level began since the time when Tarai was economically and politically controlled by hill rulers for their own political-economic interests. In an understandingof a local level Madhesi political leader of Madhes based political party, as the possession of hill rulers went on stretching in Tarai, dispossession of Madhesi community went on increasing through the imposition of policies on land holding and citizenship that were unfavorable for Madhesis living in the land since long.

By the time of long reign of Chandra Shamsher, the primacy of Birganj in the economy of Nepal was well-established (Lal, 2020). Over time, Birganj has been stood as a prime economic hub of Nepal for being an international trade and transit point. Being the "Gateway to Nepal” that hosts the largest custom point along the Indo-Nepal border, Birganj contributes vast bulk of revenue to the national treasury. However, Madhesi people living in and around Birganj have experienced the status of it as what Lal (2020) calls "milch cow." According to a local journalist belonging to the Madhesi community, the administrative

\footnotetext{
${ }^{3}$ Giri (2016) has mentioned that Siddhabir Mathema and Dhwajbir Mathema were appointed as officer of mal adda and kathmal adda respectively by Bir Shamsher and sent to Birganj for the purpose of development of Birganj as a town.

${ }^{4}$ See Giri, 2016 for brief history of arrival of Pahadi people in Birganj who were somehowrelated to the rulers in Kathmandu.
} 
officers working in Birganj and elsewhere in the Tarai, equipped with the political patronage, sought to extract the economic resources of Tarai at the expense of Madhesi people. He insists that Madhesis have given a lot to the state but have received very little; what Madhesis have received from the state are neglected and hatred.

Nonetheless, Madhesi's claim to indigenity in the Tarai seems contested as the most available evidences presented by scholars suggest that vast bulk of the Madhesi people inhabiting in the Tarai were immigrants from the adjoining Indian districts (See Dahal, 1983 and Ojha, 1983).The different groups of Madhesi people either arrived in the Tarai at different point of time from the northern India or have been settling here before the formation of Indian and Nepali state. Since the time of unification to the collapse of Rana regime, some Madhesi groups arrived in Tarai-Madhes as motivated by the combined effects of the attraction of Nepali rulers and the famine in Bihar (Dahal, 1983). In the mid1970s, Frederick Gaige noted that the Tarai population was predominantly of Indian origin, its economic and cultural ties are primarily with India and, at various times during the past two decades, it has been the stage for anti-government political activity, stimulated by dissident groups of Nepalis operating from across the border in India (Gaige, 2009). This has given rise to the contestation over Madhesis' claim on equal political power especially from the perspectives of Pahadi people.

Drawing on preceding discussions, it is suffice to say that discontents in Tarai-Madhes have been simmering because of the demographic change resulted from the influx of migrants from northern India and Nepali hills (Dahal, 1992; Ojha, 1983). Even as they accept that some migration did take place, Madhesis take offence to being called outsiders and see themselves as people who have always lived in the region (International Crisis Group [ICG], 2007) and they believe that their demand of autonomy in the Tarai is obvious.

\section{Consciousness of geopolitics}

The assertion of collective Madhesi identity became significantly powerfulin the emerging political context of federalism and democratization in Nepal.That is, the course of political transition from centralized governance to federal republican democracy provided Madhesi people a new form of imagination of their being. Madhesis have sought identification with, and political authority and control over their perceived homeland, the Tarai, especially the central Tarai based on their mythical and historical linkage to it, their demographic weight on this region and their believe that Tarai territory was laboriously constructed through the daily cultural and economic practices of them.The slogans of Whole Madhes, One Pradesh (during the regime of first constituent assembly) and ‘down with hill administration' clearly 
reflected the Madhesi politics of geopolitics of the Tarai.Such slogans were used as tactical strategy to bargain for proportionate distribution of political power and economic resources.

Madhesis' demand of autonomy has been rooted on their historically shaped perception and experiences that theTaraihas been treated as "internal colony" by the successive hill rulers (see, Shah, 2007; Lal, 2013; Sah, 2017). There has remained the dominant - dependent or center - periphery relationship between Pahad-centric rulers and marginalized Madhesi community. Thakur (1996) argues that as Madhesi region has been deprived of becoming self-governing territory, rights of Madhesi nationality have been denied; for being in "dependent condition", Madhesi community lacks the right of self-governance and has been subordinated to the administering power.Regmi (1984) mentions, "Indeed Tarai region was treated more as a colonial possession serving the economic and other interests of Kathmandu-based aristocracy and bureaucracy who were invariably of hill origin, than as a constituent unit of the newly-founded kingdom”(p. 13). Shah (2007) argues that Madhesh remained an internal colony of Khas rulers from 1768 to 1951.There is a deep down perception at the ground among Madhesis of being treated assubjects of "internal colonialism" in Nepal, where the central state extracts the resources from theMadhespopulatedplains and treats its people as secondclasscitizens, depriving them ofadequate political power and rights (S. P. Sha, 2015).For the Kathmandu elite, the flat piece of Tarai territory has historically been an area that needs to be exploited; its resources are useful, but its people are a liability (Lal, 2002).

For these reasons, Madhesishave held that state has always forced them to live in the margin politically, socio-culturally and economically and prefer to label their movement for the recognition of their collective identity as "emancipatory movement" or "movement for liberation". A youth who declined to give his identification but who continuously participated in the Birganj based Madhesi movement of 2015 despite injuries in a clash with police stated with aggressive gesture:

We (Madhesis) were begging nothing but claiming our hak (right), claiming our aajadi (liberation) from dasatwa (subordination). I don't know why the Pahadi rulers always want to be malik (owner) and tend to make us gulam (slave). Is this country their birta? Are we nothing, nobody of this country? Why Pahadis always suspect our belonging? The dominating attitude of not only Pahadi rulers but also the Pahadi people toward Madhesi community made our blood boil and led to seek aajadi, liberation, a claim of being equal citizen within our country.It was a misfortune for Madhesis that our conception of autonomy has been distorted and allegedly labeled as anti-national. The autonomy the Madhesis demand is not more than a desire of engagement of Madhesis in their own political and economic 
affairs.Madhesis now want to liberate from colonizing mindset of rulers and the state institutions that tend to sustain such mindset. (Personal Communication, March 9, 2018)

Madhesi movement was regarded by many as a long-dued awakening of the Nepali state towards the ethnic and intrinsically nationalist aspirations of the Madhesis that were never surfaced on such a scale before (Cheah, 2008, p. 14).The local journalists, politicians, students, business persons, and activistsof Birganj shared a common understanding that the policies and practices of successive governments, for the most part, have tended to isolate the Madhesis politically, economically, culturally and even psychologically;depriving the Madhesis from the access of political power, services and facilities and economic opportunities by treating them as "others", the Pahadi rulers have tried to maintain the subjugation of Madhesis. Undermining Madhesis as citizens, Pahadi rulers impertinently disregarded the rights and duties of Madhesis. So, Madhesis thrive freedom from the grip of internal colonization.

Such a consciousness among Madhesis has, in part, aroused from the geopolitical reality of the place they have inhabited. Lying at a geographical location bordering the northern India with which Madhesi people indistinguishably share their language, culture and history, its economic strength for possessing the country's most fertile agricultural land and forest resources, most of the routes for export and import of the goods to and from or via India and several industries and factories, and its socio-cultural and political complexity, all have been combined to make the distinguishing characters of Tarai-Madhes. Knowing the bare reality that Tarai-Madhes is the place of vital strategic importance for Nepal as it has been taken as the 'bread basket' for the survival of the vast bulk of Nepali population, during the Madhesi movements of different times, Madhesi political parties supported by Madhesi people waged prolonged protests even barricading the entrance of Nepal-India border at several points in the Tarai and more particularly in Birganj for more than four months to get their demands addressed. In other words, Tarai-Madhes' strategic geopolitical location and economic strength provided Madhesi people leverage to bargain at least politically with Nepali government for the fulfillment of their demands of equal citizenship.

Many Madhesis beileve that if the Tarai was not economically crucial for sustaining whole Nepal especially Kathmandu, Madhesi movement would not have reached to the climax and capable of stirring national politics. Gaige (2009) correctly noted that the plain people's control on a large share of Nepal's wealth: much of the best agricultural land in the country, much of the small-scale industry, a significant share ofthe large -scale industry, and trade between Nepal and the outside world gives them the capacity to resist the governing elite, whenever they feel threatened by it. Geopolitically, districts enroute to Kathmandu from 
India, have the power of economic blockade that can effectively disrupt life in Kathmandu for a chance to pursue political, economic or social demands with the central administration (Cheah, 2008).

Almost all of my Madhesi research participants have asserted that Madhesi people employed protest accompanied with blockade as a crucial strategy, as an ultimate resort to effectively air their issues at the national and international level; protest along with staging of sit-in at dasgaja, no men's land by disrupting the to-and-fro movement of goods was the only way for marginalized borderland people for attracting major political actors' attention. Madhesi leaders as well as people have experienced that state imposed several constraints while they were protesting in the core city areas within the limit of freedom of opinion, expression and assembly. As an excessive use of force resulting in killings and injuries continued to increase, Madhesi protesters moved southward to dasgaja. A former journalist belonging to Madhesi community of Parsa district said:

What could we do when our right to protest in capacity of citizens was terminated by the government declaring the core areas of Birganj as nishedhitchhetra, 'prohibited zone' for protest, imposing curfew for uncertain periods and using brutal force over Madhesi people indiscriminately? We strongly felt that we were in such a historical moment, in a cross-road, if we don't collectively speak and act, we won't get anything. Such a shared feeling motivated us not to get tired and give up our agenda rather to shift our acts of protest to the dasgaja, no man's land to exploit its advantage strategically by blocking the border and disrupting the flow of goods to Kathmandu with an aim to pressurize the rulers at Kathmandu to listen us. The border blockade was a last resort for agitating Madhesis to awaken the political power holders at Kathmandu. Everyday protests in Birganj have had spontaneously enormous participation from Madhesi people and obviously supported by their kin folks living across the border in India. Indeed, Madhesis during Birganj based movement expressed their potential to shake the existing unequal power structures for living in the most important landscape of Nepal. (Personal Communication, March 9, 2018)

Madhesi people took border blockade as an extreme form of protest against the government to get their demands addressed. They believed that the utility of border blockade as a tactic of protest cannot be overlooked in the future too as geography can't be changed and at least in the foreseeable future it is not feasible to establish the alternative border points in the north across China border. This implies that Madhesis have been conscious about the geopolitical reality and its impact on national political economy. 


\section{Conclusion}

The preceding discussions lead us to argue, as Karl Marx (1977) says, that it is not the consciousness of men that determines their existence, but on the contrary their social existence that determines their consciousness fits well in the case of Madhesis' consciousness. Madhesis have been organized and mobilized collectively with the consciousness of their historically shaped existence. For living in the geographically and culturally transitional region between the hills and the plains (Gaige, 2009), Madhesis have experienced that they have been misrecognized as "others" and have been mistreated by the state dominated by Pahadi people. Drawing on Ortner (2005), it can be argued that Madhesis' subjectivity seems to be a specifically cultural and historical consciousness. Here, subjectivity "means the ensemble of modes of perceptions, affect, thought, desire, fear, and so forth that animate acting subjects. The cultural and social formations that shape, organize and provoke those modes of affect thought and so on” (Ortner, 2005, p. 31). Madhesis have subjectively constructed their subjection in the context of unequal power relations. As Ortner (2005) assumes, Madhesis as actors have always been at least partially 'knowing subjects', that they had some degree of reflexivity about their geopolitical identity - their second class status and their desire of equal citizenship, and that they have some 'penetration' into the ways in which they are formed by their circumstances.

Realizing the potential of own geo-political identity, Madhesi people have become assertive of their distinct identity not only in cultural sense but for political purpose. My argument is that historically evolving geopolitics of Tarai-Madhes has provided cause and context for organizing and mobilizing Madhesi people toward a common goal of struggle for recognition. Madhesis' feeling or sense of belonging to such a place which matters a lot for the survival of majority of people of Nepal and especially for the capital Kathmandu led to mobilize themselves for asserting distinct identity. That is, the strategic positioning of TaraiMadhes has enabled Madhesis, to use Scott’s (2009) words, “keep the state at arm’s length”.

\section{References}

Bhattarai, H. P. (2000). Identities in the making: Cultural pluralism and the politics of imagined communities in the lowlands of Nepal. An unpublished dissertation submitted to the Department of Social Anthropology, University of Bergen.

Burghart, R. (1984). The formation of the concept of nation-state in Nepal. The Journal of Asian Studies, 44(1), pp. 101-125.

Cheah, F. (2008). Inclusive democracy for Madhesis: The quest for identity, rights and representation. Institute of South Asian Studies.

Dahal, D. R. (1983). Economic development through indigenous means: A case of Indian migration in the Nepal Tarai. Contributions to Nepalese Studies, 11 (1), 1-20. 
Gaige, F. H. (2009 [1975]). Regionalism and national unity in Nepal. Himal Books.

Giri, G. (2016). Birgunj: Mero saharko katha. Nepalaya

Goait, J. K. (2007). History of Tarai in Nepal: Nepalese rule in Tarai. https://madhesi.wordpress.com/2007/04/04/history-of-terai-in-nepal/

Guneratne, A. (1998). Modernization, the state, and the construction of Tharu identity in Nepal. The Journal of Asian Studies, 57(3), 749-773.

Guneratne, A. (2002). Many tongues, one people: The making of Tharu identity in Nepal. Cornell University Press.

Hachhethu, K. (2007). Madhesi nationalism and structuring Nepali state. A paper presented at an international seminar on"Constitutionalism and Diversity in Nepal" Organized by CNAS, TUin collaboration with MIDEA Project and ESP-Nepal, 22-24 August 2007.

Hamilton, F. (2007 [1918]). An account of the kingdom of Nepal and of the territories annexed to this dominion by the house of Gorkha. Rupa Publications India Pvt. Ltd.

International Crisis Group [ICG]. (2007). Nepal's troubled Tarai, Report No. 136. International Crisis Group

Jha, H. B. (2017 [1993]). The Terai community and national integration in Nepal. Adroit Publishers.

Lal, C.K. (2002). Cultural flows across a blurred boundary. In K. M. Dixit \& S. Ramachandaran (Eds.). State of Nepal. Himal Books.

Lal, C.K. (2013). Tarai-Madhesma antarik upanibeshbadko artha-rajniti. In R. Maharjan \& T. Shah (Eds.), Madhes Adhyan 2. Nepal Madhes Foundation.

Lal, C. K. (2020). The story of Birganj: The emergence, disruption and continuity of cities in the Madhes. Studies in Nepali History and Society, 25(1), 175-208.

Marx, K. (1977). A contribution to the critique of political economy. Progress Publishers.

Michael, B. A. (1999). State making and space on the margins of empire: Rethinking the AngloGorkha war of 1814-1816. Studies in Nepali history and society, 4(2), 247- 294.

Michael, B. A. (2011). The Tarai: A part of Moghlan or Gorkha? In A. Guneratne (Ed.), The Tarai: History, society, environment. Himal Books.

Michael, B. A. (2013). State making and territory in south Asia: Lessons from the Anglo-Gorkha war (1814 - 1816). Anthem Press.

Ojha, D. P. (1983). History of land settlement in Nepal Tarai. Contributions to Nepalese Studies, 11(1), 21-44.

Ortner, S.B. (2005). Subjectivity and cultural critique. Anthropological Theory, 5, 31-52.

Pathak, B. and Uprety, D. (2009). Tarai-Madhes: Searching for identity based security. Conflict Study Center.

Rai, J. (2013). Activism as a moral practice: Cultural politics, place making and indigenous movements in Nepal. An unpublished dissertation submitted to the University of Michigan, USA.

Regmi, D. R. (2007 [1961]). Modern Nepal: Volume I and II. Rupa \& Co.

Regmi, M. C. (1972). A study in Nepali economic history. Adroit Publishers. 
Regmi, M. C. (1978). Thatched huts and stucco palaces: Peasants and Landlords in $19^{\text {th }}$ century Nepal. Adroit Publishers.

Regmi, M. C. (1984). The state and economic surplus: Production, trade, and resource mobilization in early $19^{\text {th }}$ century Nepal. Nath Publishing House.

Rose, L. E. (1971). Nepal: Strategy for survival. University of California Press.

Sah, R. M. (2017). The middle country: The traverse of Madhes through war, colonization and aid dependent racist state. Adroit Publishers.

Scott, J. C. (2009). The art of not being governed: An anarchist history of Southeast Asia. Yale University Press.

Sha, S. P. (2015). Why the Madhesi people revolted in Nepal. http://southasiamonitor.org/detail.php?type=sl\&nid=13692

Shah, S.G. (2006). Social inclusion of Madhesi community in nation building. Civil Society Forum Workshop for Research programme on social inclusion and nation building in Nepal, Organized by Social Inclusion Research Fund (June, 2006).

Shah, S. G. (2007). Peaceful resolution of ethnopolitical movement in Nepal Madhes. https://madhesi.wordpress.com/2007/07/23/peaceful-resolution-of-ethnopoliticalmovement-in-nepal-madhesh/

Shrestha, Nanda R. (2001 [1990]). The political economy of land, landlessness and migration in Nepal. Nirala Publications.

Stiller, L. F. (1993). Nepal: Growth of a nation. HRD Research Center.

Stiller, L. F. (2018 [1976]). The silent cry: The people of Nepal - 1816 - 1839. Education Publishing House.

Thakur. R. N. (1996). Paratantra Madhes aur uski samskriti. In M. Thakur (Ed.), Amar sahid Raghunath Thakur Madhesi ka jivan-brita aur unki kritiya. Mahananda Thakur.

Whelpton, J. (2005). A history of Nepal. Cambridge University Press. 